\title{
縦軸ポンプヘの取水槽からの空気吸込の発生条件*
}

\author{
平田 勝哉 ${ }^{* 1}$, 舟木 治郎 ${ }^{* 1}$, 久保田 義啓 ${ }^{* 2}$ \\ 稲垣 勝久 ${ }^{* 2}$, 田岡 未樹 ${ }^{* 2}$, 斉田 拓也 ${ }^{* 2}$
}

\section{Occurrence Condition of Air Entrainment into a Vertical Wet-Pit Pump}

\author{
Katsuya HIRATA*1, Jiro FUNAKI, Yoshihiro KUBOTA, \\ Katsuhisa INAGAKI, Miki TAOKA and Takuya SAIDA
}

${ }^{* 1}$ Department of Mechanical Engineering, Doshisha University, Kyoto 610-0321, Japan

In the present study, we consider the air entrainment into a suction pipe which is vertically inserted down into a suction sump across a mean free-water surface. This configuration is often referred to as the "vertical wet-pit pump", and has many practical advantages in construction, maintenance and operation. In particular, we focus our concern upon the critical submergence depth $S_{\mathrm{c}}$, which is one of the prime and conventional indicators for the air-entrainment occurrence. By a systematic approach, we experimentally investigate the influences of kinetic and geometric parameters upon $S_{\mathrm{c}}$. As the kinetic parameters, we consider the Reynolds number $R e$ and the Weber number We, in addition to the Froude number $F r$, on such a basis as $F r$ is not much larger than unity in many actual cases. As the geometric parameters, we consider back clearance $X$, sump breadth $B$ and bottom clearance $Z$. All these parameters are non-dimensionalised by the outside diameter $D$ and the intake velocity $V_{\mathrm{i}}$ of the suction pipe. As a result, we reveal the effects of such six parameters upon $S_{\mathrm{c}}$. The We effect, namely, the surface-tension effect can be ignored at $W e>12$. And, the $R e$ effect, namely, the viscous effect becomes negligibly small at $R e>3 \times 10^{4}$. Under such conditions for $W e$ and $R e$, we could consider only the $F r$ effect, namely, the gravitational effect. Concerning the $X / D$ and $B / D$ effects, $S_{\mathrm{c}} / D$ attains the maximum at a certain $X / D$ or $B / D$. On the other hand, the $Z / D$ effect is monotonical, and becomes small at $Z / D>2.5$. Some aspects of these geometric effects can be evaluated by a local-Froude-number effect on the basis of the global relation between $S_{\mathrm{c}} / D$ and $F r$. And, the other aspects is necessarily considered to be related with the flow structure in the suction sump.

Key Words : Pumps, Air Entrainment, Vortices, Open Sump, Water Intake, Two-Phase Flow

\section{1. 緒言}

発電プラントや灌泊設備，排水施設などでは，イニシャル・コストの削減や小型化，高効率化，高性能化の実 現のため, 吸込水槽の最適設計が必要とされる. 近年, それらの要求を満たすためのより高水準な解決策が求め られている．そのような状況下では，吸込管入口への空気吸込が起りや寸くなる．空気吸込は，大きな騒音を発 生させる他, 振動, 揚水効率低下, そして最悪の場合はポンプ崩壊を引き起こす.よって, 空気吸込を防ぐよう, 入念な吸込水槽と吸込管の設計が求められる.

* 原稿受付 2013 年 1 月 11 日

*1 正員, 同志社大学 理工学部（产610-0321 京都府京田辺市多々羅都谷 1-3）

*2 同志社大学理工学研究科

E-mail:khirata@mail.doshisha.ac.jp 
吸込水槽では空気吸込が実用的局面での最重要事項の一つであるので，これまでに空気吸込に関する多くの研 究がなされてきた.

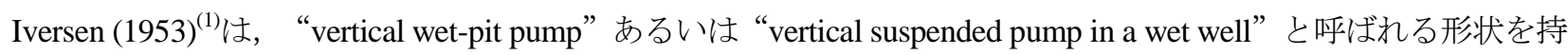
つ単純なモデルを考えた。 そこでは，吸込管が自由表面を貫いて垂直に吸込水槽に挿入される。この形状は，水 力学上最適ではないが，構造や維持管理，操作において，多くの実用的な利点がある.ここで，吸込管は円形断 面を有する直線状パイプであり，吸込水槽は開水路である。この開水路は，吸込管の下流で，垂直な背面を有す る (図1を参照)。そのような簡単な形状にも関わらず，この吸込水槽内の流れは，非常に複雑である。例えば, 空気吸込の基礎研究の為によく調べられてきた水平オリフィス内流れ (後述) と比較しても, ずっと複雑である. Iversenは，既存の吸込水槽内の流れを，“局所渦”や“柱状渦”などのいくつかのタイプに分類した．彼の研究 は，先駆的なものであるが，首尾一貫した次元解析を欠いており，また，定性的なものであった，一方で，彼は， フルード数Frを唯一の運動パラメータとして考えるだけでは空気吸込を規定するのに不充分であること，つまり， 別の力学パラメータがこの現象を規定するのに更に必要であることを, 結論づけている. Fraser \& Harrison (1953) ${ }^{(2)}$ は, 複雑形状を有するいくつかの吸込水槽に生じる空気吸込を報告した. Denny (1956) ${ }^{(3)}$ は, 簡単な幾何形状と複 雑な幾何形状の吸込水槽の両者について, 様々な形状効果を調査した. 彼は, 実務的観点から, 空気吸込のスケ 一ル効果に最も重要なパラメータとして, Frなどの無次元量の代わりに，吸込管入口の有次元流速を提案した. ここで, スケール効果とは，すべての力学パラメータ効果を包括したものを指す.

Stevens \& Kolf $(1957)^{(4)}$ は，最も簡単な問題の一つである“水平オリフィス”（あるいは “horizontal orifice”， “circular-drain basin”）を対象にして，重力および粘性，接近流の循環，幾何形状に関する4つの無次元パラメー タについて考えた. Hattersley $(1965)^{(5)}$ は, 修正vertical-wet-pit-pump形状を含むいくつかの複雑形状を持った吸込水 槽の実際の運転状況下での諸特性を報告した. 更に, 彼は, いくつかの実用的な空気吸込の防止方法を提案した. また, Iversen と同様に, 彼は, 空気吸込現象を規定する為に, Frに加えて, 他の運動パラメータが必要であると 指摘した.

Granger $(1966)^{(6)}$ とAnwar $(1966)^{(7)}$, Maris $(1967)^{(8)}$, Zielinski \& Villemonte (1968) $)^{(9)}$ は, Stevens \& Kolf と同様に, 水 平オリフィスを研究対象とした. Grangerは定常かつ軸対称の仮定の下, 微小擾乱を考え粘性解析解を導き, 実験 と比較した。一方, Marisは非粘性の仮定下, 粘性一次近似のもとで解析解を求め, 渦度の時間発展を調べた. AnwarとZielinski \& Villemonteは, 流量係数への粘性および接近流の循環, 幾何形状の影響を示した. Anwarによ ると半径レイノルズ数 $R_{S}(\equiv \pi Q /(v S)) \geq 10^{3}$ の時, Zelinski \& Villemonteによるとレイノルズ数 $R e_{\mathrm{ti}}\left(\equiv \pi D V_{\mathrm{ti}} / v\right) \geq$ $1.0 \times 10^{4}$ の時, 粘性効果を無視できる.ここに， $Q$ および $v, S, D, V_{\mathrm{ti}}$ は, それぞれ，吸込口での流量および動粘 度, 水深, 吸込口直径, 理論平均流速である。

Anwar (1968) ${ }^{(10)}$ とDomm et al. (1971) ${ }^{(11)}$ も，Hattersleyと同様，“vertical-wet-pit-pump” 形状を含む様々な吸込水槽 を調查して, いくつかの空気吸込の防止方法を提案した. 彼らの研究は, 次元解析上の一貫性を欠いているのだ

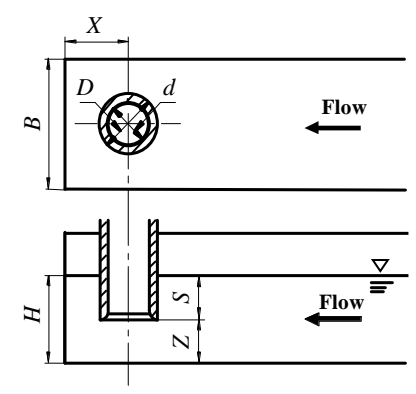

Fig. 1 Suction sump and suction pipe, with the vertical-wet-pit-pump configuration. $D$, Outside diameter of a suction pipe; $d$, inside diameter of a suction pipe; $B$, sump breadth; $X$, back clearance; $H$, water level; $S$, submergence depth; $Z$, bottom clearance. 
が，吸込口没水深さ $S$ と接近流の循環の両方が旋回流れに大きな影響を及ぼす点を強調している．一方，近藤と 丸(1972) ${ }^{(12)}$ は，単純な “vertical-wet-pit-pump” 形状を対象にして，縮尺モデル試験のための折衷規範を提案した. 彼らの折衷規範は，Fr相似則と吸込管入口の有次元流速一致則の中間則である.もちろん，この折衷規範は，レ イノルズ数Re相似則から，はるかに懸け離れている.

Reddy \& Pickford (1972) $)^{(13)}$ は, 吸込水槽背面に水平吸込口を持つ“垂直オリフィス”（あるいは“vertical orifice” ) を調查した．“垂直オリフィス”とは水平な吸込口を持つ吸込水槽である．彼らは，Fr相似則を前提として， $S_{\mathrm{d}}$ $D=F r$ なる経験則を提案した。 また，より実用的規範として $S_{\mathrm{c}} / D=F r+1$ も提案した.

Levi $(1972)^{(14)}$ は，さまざまな水平オリフィスを実験的に調べ，その流れの，竜巻など気象現象への応用を提案 した. Dagget \& Keulegan $(1974)^{(15)}$ は, グリセリン水溶液や種々の混合油など数種類の作動流体を使用することで, 水平オリフィスで包括的な実験を行った．彼らの実験では，定常状態にある空気糸が自由表面から吸込口まで存 在する. なお, 以前行われた水平オリフィスの基礎研究の多くは, 空気吸込を伴わない条件下での調査であった. 彼らは, ウェーバー数We（定義は後述）の効果, さらに, $F r$ と $R e$, 接近流循環係数 $N_{\Gamma}$, 二つの幾何形状パラメ 一タの効果について，調べた，We効果（または，表面張力効果）に関する詳述を欠いているが，彼らは，流量係 数へのWe効果を無視できると指摘した. また, 彼らは, $R e$ 効果（または, 粘性効果) が, $R e\left(\equiv V_{\mathrm{i}} D / v\right) \geq 3.2 \times 10^{4}$ のとき，無視できると結論付けた．ここで， $V_{\mathrm{i}}$ の定義は後で示す．彼らと同様，We効果および $F r$ 効果（または，

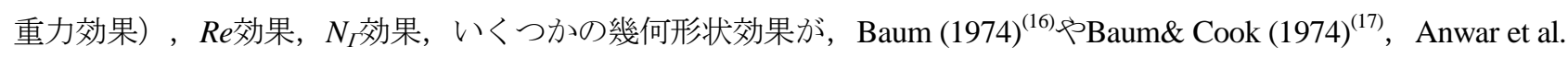
$(1978)^{(18)}$, Jain et al. (1978) $)^{(19)}$ によって議論された. BaumとBaum \& Cookは, さまざまな流体 (sodium, 水, white spirit, Freon 113）を用いた実験を行った. Baum \& Cookは, Re効果を無視して $S_{\mathrm{d}} / D_{\mathrm{t}}=700\left(F r^{0.5}-4.4 F r / W e\right)$ を提案した. ここに， $D_{\mathrm{t}}$ は円柱水槽直径である. Anwar et al.は，“水平オリフィス”の代わりに，吸込水槽側面に吸込口を持 つ“垂直オリフィス”を調查した．彼らの結論では，We効果とRe効果の両方が，We $\left(\equiv \rho Q^{2} S /(A \sigma)\right) \geq 10^{4}$ かつ $R e_{S}$ $(\equiv Q / v S) \geq 3.0 \times 10^{4}$ のときに無視できる. 前者と後者の条件は，それぞれ，We $\geq 41-71$ とRe $\geq 2.3 \times 10^{4}-3.8 \times 10^{4}$ に対 応する. ここで, We とReの換算值は一定ではなく, Frの值に伴い変わることに注意すべきである．なぜならば， 彼らの実験装置では, いくつかの形状パラメータが一定值に固定されており, また, 一種類の作動流体, つまり, 水だけが使用されている. 一方, Jain et al.は，二つのサイズの吸込水槽と三種類の作動流体（水, セルロース水 溶液, アルコール水溶液）を使用して, 整合性のある水平オリフィス実験を行った. 彼らは, 接近流の循環が大 きくなるにつれて, 臨界没水深さ $S_{\mathrm{c}}$ (定義は後述) が大きくなる, 寸なわち, 空気吸込がより起こり易くなると 考えた．この概念のもとに解析された実験データは，その仮定の正当性を示した．彼らの結果によると，We 11 でWe効果を， Re/Fr ${ }^{2} \geq 5.0 \times 10^{4}$ でRe 効果を，それぞれ，無視できる．Hecker $(1981)^{(20)}$ は，様々なモデルと原型との 比較により, 以前の研究における寸法効果を要約した. Farell \& Cuomo (1984) ${ }^{(21)}$ と Padmanabhan \& Hecker (1984) ${ }^{(22)}$ は, Re 効果は高Reで無視できることを確認した. もっとも, 両研究では, We 効果は考察対象外であった. Odgaard $(1986)^{(23)}$ は，軸対称の層流を想定し， $S_{\mathrm{c}}$ と $F$ や $N_{\Gamma}, R e ， W e$ とを関連付ける寸法効果規範を提案した。

Gulliver \& Rindels (1987) ${ }^{(24)}$ やTakahashi et al. (1988a, 1988b) ${ }^{(25),(26)}$ はvertical-downward flowing intakeについて, 空気 吸込を実験的に調心゙, 空気吸込の発生条件を $F r や N_{\Gamma}$ （あるいは, 回転フルード数）の関数とする経験則を提案し ている. Hite Jr \& Mih (1994) (27) も吸込水槽側壁に吸込口を持つ vertical orificeについて, 高Reかつ高Weにおいて, $R e$ 効果とWe効果を無視し,$F r$ と $N_{\Gamma}$ の影響を明らかにした. Yildirim \& Kocabas $(1995,1998)^{(28),(29)}$ はvertical-downward flowing intakeについて考え, $W e, F r, R e, N_{I}$ 効果を無視し, 流速比と幾何形状パラメータについてのみ明らかに している.

最近, Werth \& Frizell (2009) ${ }^{(30)}$ はvertical-wet-pit-pump水槽について, Gulliver \& Rindels (1987)の経験則を修正し $S_{\mathrm{c}} / D=2.1+4 F r^{2 / 3} / 3$ を提案した。 これは, ANSI $の 1998 \mathrm{HI}$ Standard（ $S_{\mathrm{c}} / D=1+2.3 F r$, 後述 $)$ よりも, よい近似を 与える. 
上述の研究の内，整合性のある次元解析は，水平オリフィスなどの最も簡単な形状でのみ取り扱われている. なぜならば，形状パラメータの少ないそのような単純流れに対してのみ, 整合的な取り組みが適用可能なためで ある．しかしながら，実際の吸込水槽（例えば，Iversen (1953)やFraser \& Harrison (1953)に見られる）は，しばし ば, 流体力学以外に及ぶ広範囲の実用上の制限や要求のため, 複雑な形状を有する. 残念ながら, 現状では単純 なvertical-wet-pit-pump形状のような, わずかに複雑な形状の吸込水槽についてさえ我々の知識は充分でない. そ の様なわずかに複雑な形状の吸込水槽に水平オリフィスの知識を適応することも考えられるが, 一般的に単純で はない. なぜなら, 水平オリフィスで想定した $N_{\Gamma}$ の值を, 複雑形状の吸込水槽で見積もることは容易ではない. つまり、複雑形状の吸込水槽内で流れは，完全に三次元的であり（軸対称ではなく），かつ，非常に弱い周期性 を伴う強非定常性を示す.この様な状況下で, $N_{\Gamma}$ は通常, 力学パラメータと幾何学パラメータの両方の関数とし て与えねばならないからである.

本研究では, 吸込管が自由表面を貫通して垂直下方に吸込水槽に挿入される, いわゆる, vertical-wet-pit-pump 形状での空気吸込を考える. 特に, 没水深さ $S_{\mathrm{c}}$ に注目する.ここで， $S_{\mathrm{c}}$ は，空気吸込発生のための重要かつ慣例 的に使用される尺度である。

vertical-wet-pit-pump の形状は, 実用的な利点が多い. よって, これまでに理論と実務の双方の視点から, 多 くの研究がなされてきた。 それらには, Iversen (1953), Denny (1956), 藤田と大谷(1962) ${ }^{(312}$, Hattersley (1965), 京極 $(1965)^{(32)}$, Anwar (1968), 北村と木田(1971) $)^{(33)}$, 近藤と丸(1972), 五十畑ら(1975) ${ }^{(34)}$, 田籠(1976) $)^{(35)}$, 窪田 $(1978)^{(36)}$, 新浜ら $(1983)^{(37)}$, 岡本ら $(1991)^{(38)}$, 田籠と上田 $(1991)^{(39)}$, Arboleda \& El-Fadel $(1996)^{(40)}$, Constantinescue \& Patel (1998) $)^{(41)}$, Werth \& Frizell (2009)や最近の著者らの研究(Funaki et al. (2008) ${ }^{(42)}$ と Hirata et al. (2009) $\left.{ }^{(43)}\right)$ などが ある. Funaki et al.では, 空気吸込メカニズムを明らかにするために, 超音波ドップラー法を使用して, 吸込水 槽内の典型的な三次元時間平均流れ場, 寸なわち, 時間平均速度分布や渦度分布を示している. Hirata et al.で は，単純なコンダクタンスタイプの気泡センサーを製作し，空気吸込の正確な計測を行い，従来法での結果と

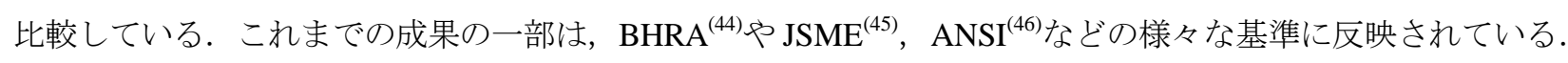

なお, 空気吸込と力学的に類似した現象として不連続密度成層からの選択取水がある. 選択取水は, 環境問 題やエネルギー／資源問題に関係し，これまで活発に研究されてきた，その内，本研究と特に関係が強いもの として, 垂直オリフィス問題が挙げられる（Lubin \& Springer (1967) $)^{(47)}, \quad$ Jirka \& Katavola (1979) ${ }^{(48),}$ Forbes \& Hocking (1995) $\left.{ }^{(49)}\right)$.

これまでの vertical-wet-pit-pump 形状に関する研究では, いくつかの形状効果について議論しているが, それ らの結果は, 様々な力学パラメータ効果すなわち寸法効果を包含しており, その徹底的な議論の欠如のため, 一般性に乏しい. 実際, 過去のいくつかの研究では, スケールモデル試験の結果を矛盾なく説明するためには, Frに加えて他の力学パラメータが必要であると結論付けている. そこで, 本研究では, 整合性を保証した一連 の実験により, 六個の無次元パラメータが $S_{\mathrm{c}}$ 一及ぼす効果の解明を試みる. 六個の内の三個のパラメータは力 学効果, 寸なわち, 重力効果および粘性効果, 表面張力効果に関するものであり, 他の三つのパラメータは幾 何形状効果に関するものである.

\section{2. 実験方法}

\section{$2 \cdot 1$ 吸込水槽と吸込管}

図 1 は, 今回対象とするモデルを示す. 寸なわち, 単純な vertical-wet-pit-pump 形状を持った吸込水槽/吸込 管系である. ここに， $D$ と $d$ とは，それぞれ，吸込口の外径および内径である. 前者は, 本論では代表長さス ケールとする. 後者は， $0.9 D$ に固定する. 吸込管の吸込口形状は, ベルマウス型である. 基礎研究として形 状パラメー夕数を減じるべく, ベルマウス外径も吸込管外径と同じ $D$ とする.（なお，本実験は，田籠(1976) 
Table 1 Experimental parameters.

\begin{tabular}{|c|c|}
\hline$B[\mathrm{~m}]$ & $0.033-0.150$ \\
\hline$X[\mathrm{~m}]$ & $0.020-0.215$ \\
\hline$Z[\mathrm{~m}]$ & $0.007-0.023$ \\
\hline$D[\mathrm{~m}]$ & $0.014-0.048$ \\
\hline$V_{\mathrm{i}}[\mathrm{m} / \mathrm{s}]$ & $0.45-1.20$ \\
\hline$B / D$ & $1.43-5.30$ \\
\hline$X / D$ & $0.79-5.0$ \\
\hline$Z / D$ & $0.26-3.21$ \\
\hline$H / D$ & $0.53-6.05$ \\
\hline$F r$ & $0.66-2.8$ \\
\hline$R e$ & $8.3 \times 10^{3}-4.6 \times 10^{4}$ \\
\hline$W e$ & $8.6-27$ \\
\hline$R e / F r^{2}$ & $2.3 \times 10^{3}-4.9 \times 10^{4}$ \\
\hline$B o$ & $20-500$ \\
\hline
\end{tabular}

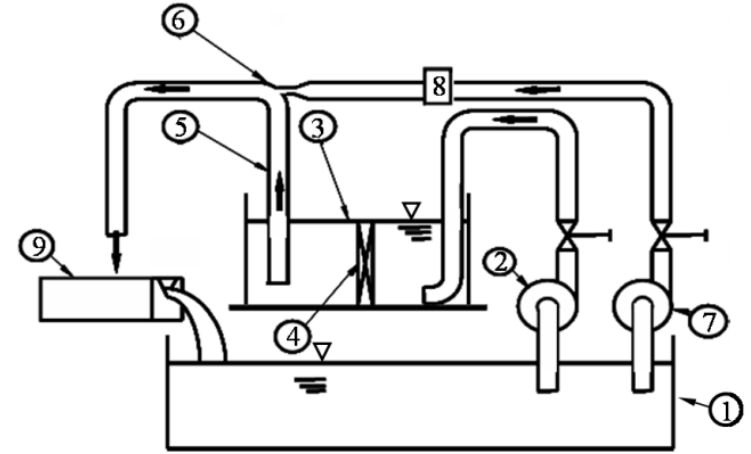

Fig. 2 Experimental apparatus1. 1, Reservoir; 2, Turbo pump A; 3, Suction sump; 4, Strainer; 5, Suction pipe; 6, Bend-type jet pump; 7, Turbo pump B; 8, Eletro-magnetic flow meter; 9, Triangle weir.

によると，ベルマウス外径（=D）が $S_{\mathrm{c}}$ にほとんど影響をおよばさない範囲（1.75d 以下）にある.）吸込管は 吸込管中心から吸込水槽後壁までの間隙, 吸込管入口と吸込水槽底壁との間隙を示寸.また， $H$ は，水位，す なわち，平均自由水面の高さである，よって，パイプの没水深さ $S$ は， $(H-Z)$ に等しい，代表速度スケールを 吸込管入口の平均流速 $V_{\mathrm{i}}$ とする， $V_{\mathrm{i}}$ は，以下のように定義する.

$$
V_{\mathrm{i}}=4 Q /\left(\pi D^{2}\right) \text {. }
$$

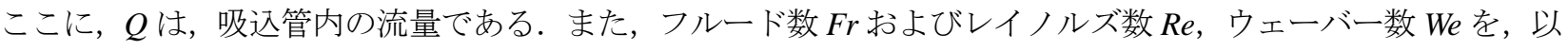
下のように定義する.

$$
\begin{aligned}
& F r=V_{\mathrm{i}} /(g D)^{0.5} . \\
& R e=V_{\mathrm{i}} D / v . \\
& W e=V_{\mathrm{i}}(\rho D / \sigma)^{0.5} .
\end{aligned}
$$

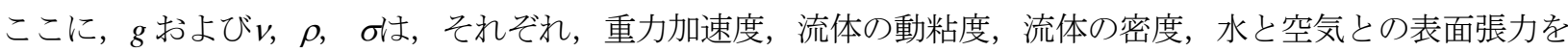
示す. また，過去の研究ではWeの代わりに, Bond 数 Bo を考えることがある. Bo は以下のように定義する.

$$
B o=\rho g D^{2} / \sigma \text {. }
$$

表 1 は，本研究における実験パラメータとそれらの範囲を，無次元形状パラメータおよび無次元運動パラメ 一タと共に示す.

図 2 は，本実験装置の概略を示す，ターボ・ポンプ A(図中，No.2)は，作動流体(水)を貯水槽(No.1)から吸込 水槽(No.3)に送る. 制御弁により, ポンプ A の流量を調節して, 吸込水槽の水位 $H$ を定める. 吸込水槽の上流, すなわち, 吸込水槽後壁から $0.84 \mathrm{~m}$ 上流に, 整流装置(No.4)を設ける. 整流装置は直径 $0.001 \mathrm{~m}$ かつ隙間 0.001 $\mathrm{m}$ のワイヤー・メッシュ 2 枚によって挟まれた, 不織布から成る. ベンド・タイプ・ジェット・ポンプ(No.6) により, 吸込水槽から吸込口(No.5)に水を吸い上げる. このジェット・ポンプは, ターボ・ポンプ B(No.7)によ り, 駆動する. ここで, ジェット・ポンプは, 通常の軸流ポンプなどと比較して, 旋回流成分が小さい特徴を 
有する. 電磁流量計(No.8)により, ジェット・ポンプの一次流量を測定する. また, 三角堰(No.9)により, ジェ ット・ポンプの一次流量と二次流量の総和を測定する.ここで, 二次流量は, 吸込管内の流量に等しい. 最後 に，三角堰からの水は，貯水槽に戻され，水の循環系が閉じる.

\section{$2 \cdot 2$ 自由表面形状の分類}

Iversen (1953)や Denny (1956), Prosser (1977) ${ }^{(44)}$, 豊倉ら(1984) ${ }^{(45)}$, Padmanabham \& Hecker (1984)を参考にしつ つ, 予備観測を実施し, 吸込水槽内に特有の自由表面パターンを, 五つのタイプ(a)-(e)に分類する (図 3 を参 照).

この分類法は，特に吸込管への空気吸込に注目したものである．考察の容易性と確実性とを重視した結果， 本分類は, $\mathrm{BHRA}^{(44)}$ やSMEE ${ }^{(45)}$ の分類法に近く, 染料などによる流れの可視化を伴う $\mathrm{ANSI}^{(46)}$ の分類法とは, 若 干異なる.

以下に，五つのタイプ(a)-(e)を説明する.

タイプ(a): 図3(a)に示すように，吸込管付近の平均自由表面に浅いへこみ，すなわち，くぼみを観測できる.

くぼみの多くは，吸込管の下流に発生する。ここで，くぼみからの空気吸込はないことに注意すべ きである.

タイプ(b): 図 3(b) と図 4(a) とに示すように, 空間的に断続した空気糸, すなわち, ある線上に一列に連なった 一連の気泡を，観測できる．空気糸の一端は，平均自由表面のくぼみへと続く．タイプ(a)と同様， 空気糸の多くは吸込管下流に発生し，空気糸を中心軸として，その周囲の流体が旋回する．この夕 イプでは，吸込管への空気吸込は起こりえるが，吸込まれる空気は，微量である（例えば，五十畑 ら(1975)を参照)。

タイプ(c): 図 3(c) と図4(b) とに示寸ように，空間的に連続した空気糸，すなわち，平均自由表面から吸込管入

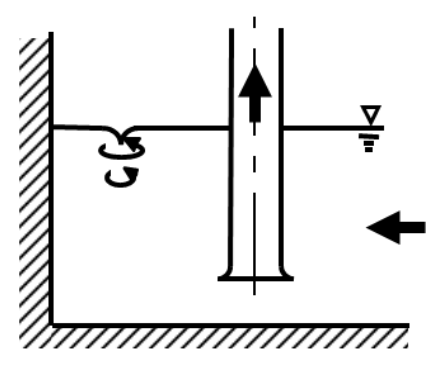

(a) A free-surface dimple near a suction pipe

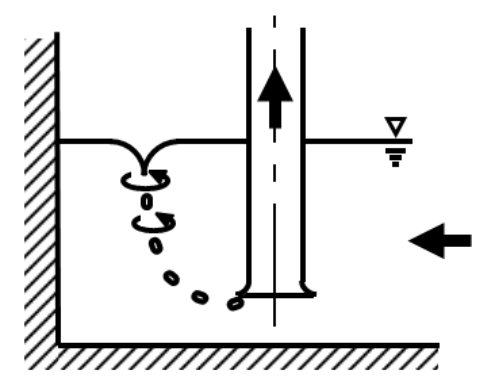

(b) A spatially-intermittent air

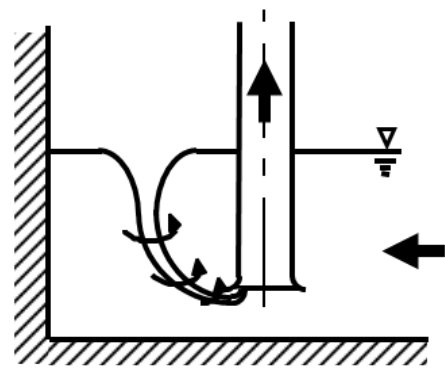

(c) A spatially-continuous air string near a suction pipe string near a suction pipe

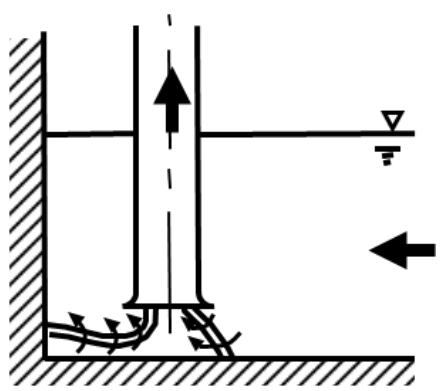

(e) Submerging air strings

(d) A free-surface hollow exposed to the peripheral wallof a suction pipe

Fig. 3 Types of distinctive free-surface patterns in suction sumps. 
ロへ至る自由表面上の深いくぼみを，観測できる．タイプ(a)やタイプ(b)と同様，空気糸は，一般に 吸込管下流に発生し，流体旋回の中心軸となる，このタイプでは，吸込まれる空気の量は大きく， 通常ポンプ性能への影響を無視できない.

タイプ(d): 図3(d)に示すように, 吸込管外周壁に接する平均自由表面に大きなくぼみを観測できる.くぼみは, 吸込管の一部あるいは全部を取り囲む. 流体は, 時に, 吸込管周囲を旋回寸ることがある. 空気は, 吸込管周囲の任意の場所から，不規則に吸込まれ，ポンプ性能に致命的な影響を与える.

タイプ(e): 図3(e)に示寸ように，水中空気糸が観測できる．この自由表面境界は平均自由表面に連結していな い.つまり，空気系の一端は，吸込管入口に達しており，もう一端は，吸込管の底壁あるいは側壁， 後壁に達する．他のタイプと同様に，空気糸は流体旋回の中心軸となる.

吸込水槽内では, 自由表面パターンは, 没水深 $S$ の減少とともに, 通常, タイプ(a)からタイプ(d)へと移行す る. 一方, タイプ(e)は平均自由表面の存在とは, 直接, 関係がない. 換言すれば, たとえ $S$ が大きい時でも, タイプ(e)は出現し得る. 以上の分類法は, 空気と水との間の自由表面の目視観測に基づいた慣例的なものであ ることに注意すべきである. よって，どのタイプも，空気吸込の発生にも吸込空気量にも直接関係づけること はできない。

\section{$2 \cdot 3$ 臨界没水深 $\mathcal{S}_{c}$}

多くの研究者と同様, 本研究では, 空気吸込の第一の指標を, 臨界没水深 $S_{\mathrm{c}}$ とする. $S_{\mathrm{c}}$ の定義は, 以下の通 りである. 没水深 $S$ (図 1 を参照)が充分大きい值から零まで減少するとき，まず， $S=S_{\mathrm{c}}$ において空間的に連続 した空気系(タイプ(c))が最初に観察できる（もちろん，タイプ(a)とタイプ(b)は， $S>S_{\mathrm{c}}$ でも観察できる). 本実 験では, $S$ を $0.005 \mathrm{~m}$ 間隔で段階的に減少させる. 各段階では, 各々 5 分間, タイプ(c)を捜索する. なお，予備 試験により，タイプ(c)発生の周期性は非常に弱いが，5 分間の観測は，タイプ(c)を確認するのに充分であるこ とも確認した. タイプ(c)の発生は, 吸込管への空気吸込の発生を直接意味しないが，空気吸込発生の充分な指 標にはなり得る(Hirata et al. (2009)を参照). また，タイプ(c)の発生は，実用的観点からも，指標として注目され ている（五十畑ら(1975)，豊倉ら(1984)）。

\section{3. 結果と考察}

\section{$3 \cdot 1$ 支配パラメータ}

臨界没水深さ $S_{\mathrm{c}}$ に影響を及ぼす有次元量九個を考える. 寸なわち，吸込管入口流速 $V_{\mathrm{i}}$ および吸込管外径 $D$,

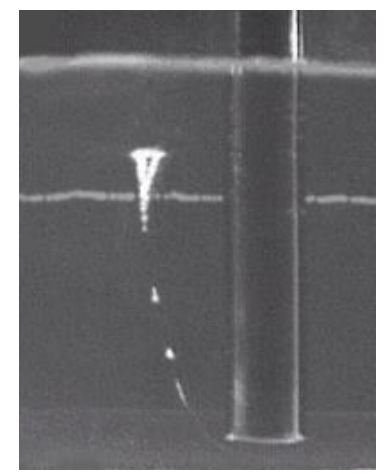

(a) Spatially-intermittent air string from the atmosphere to a suction-pipe intake

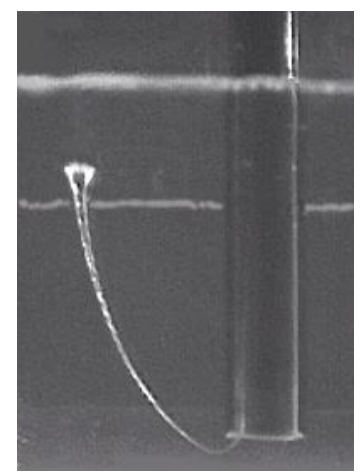

(b) Spatially-continuous air string from the atmosphere suction pipe intake

Fig. 4 Photographs of air strings. 
吸込水槽幅 $B$, 後壁間隙 $X$, 底壁間隙 $Z$, 重力加速度 $g$, 表面張力 $\sigma$, 流体密度 $\rho$, 流体粘性係数 $\mu$ である. 次 元解析より, 次式を得る.

$S_{\mathrm{c}} / D=\Phi_{1}(F r, R e, W e, B / D, X / D, Z / D)$.

ここに， $\Phi_{i}$ は任意関数(整数 $\left.i=1,2,3, \cdots\right)$ である.

式(6)において， $V_{\mathrm{i}}$ と $D$ とを，それぞれ，代表速度スケールと代表長さスケールとして選ぶ. もし，本現象で 最も重要な力を，慣性力の代わりに重力と見なすならば，式(6)に代わり，次式を得る.

$S_{\mathrm{c}} / D=\Phi_{2}\left(F r, \operatorname{Re}^{2} F r^{2}, B o, B / D, X / D, Z / D\right)$.

以下の節では，式(6)または式(7)を想定して， $S_{\mathrm{c}} / D$ への六個の無次元支配パラメータ $(F r$ と $e, W e, B / D$, $X / D, Z / D)$ ，または， $\left(F r\right.$ と $R e / F r^{2} ， B o, B / D, X / D, Z / D ）$ の効果の解明を試みる.

式(6)と式(7)のどちらを考えるか, すなわち，第一に支配的な力が慣性力か重力かは，自由表面の現象を考え る上で最も重要な力学パラメータである Fr の值に依存する. (Iversen (1953)と Hattersley (1956)を参照). Fr « 1 においては式(6)を，Fr»1 においては式(7)を用いるべきである．Fr ${ }^{2}$ は，慣性力の重力に対する全体的なバラン スを表している. そして, それら二つの力は, 自由表面現象を支配する主要な力である. それら二つの主要な 力のバランスを変更する補助的な力として, 粘性力と表面張力とを考えることができる. よって, 慣性力が重 力よりも小さくなりがちな $F r \ll 1$ のき, それら二つの補助的な力は, 重力ではなく慣性力の大きさに近づく. そして，それら二補助力と慣性力との関係は，二補助力と重力との関係よりも，より流れに影響を及ぼしやす くなる。そして，Fr»1では，その逆となる.

実用上, Fr は多くの場合 1 よりもずっと大きくなることはないので, 式(7)よりも式(6)の方が有用であろう. この考えに基づくと, 力学パラメータとして,$F r$ に加えて $\operatorname{Re}_{F} \mathrm{r}^{2}$ や Bo ではなく, $\operatorname{Re}$ や We を考えるべきで あろう。

また，代表速度スケールとして， $V_{\mathrm{i}}$ の代わりに別の量を使用できる. 例えば，代表速度スケールとして，吸

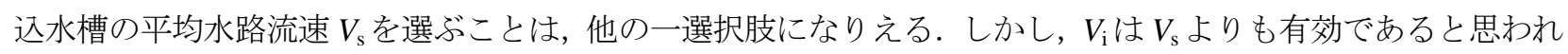
る. なぜならば，吸込管入口付近の局所流れは，より空気吸込に影響を与え得る. さらに， $V_{\mathrm{i}}$ の使用は $V_{\mathrm{s}}$ と比

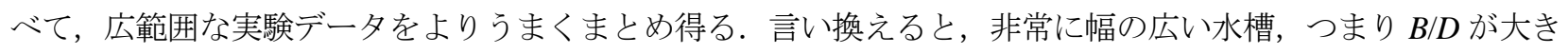
い時， $V_{\mathrm{s}}$ は非常に小さい值をとる. 一方で， $V_{\mathrm{s}}$ の使用は接近流がより効果的になる様な狭いパラメータ範囲内 では有効と思われる. 代表速度スケールと同様, 代表長さスケールとして $D$ の代わりに別の量を使用できる. 例えば，代表長さスケールとして $B$ を選ぶことは，他の一選択肢であろう。しかし，代表速度スケールと同様 な議論により，DはBよりも有効であると思われる.

\section{3-2 カ学パラメータの影響}

今, 式(6)中の三つの力学パラメータ $F r$ と $R e, W e$, および, 式(7)中の三つの力学パラメータ $F r$ Re/Fr ${ }^{2}$, $B o$ の, $S_{\mathrm{c}} / D$ への影響を考える. もし, 複数の力学パラメータの複合効果の代わりに, 一つの力学パラメータだ けの純粋な効果を知りたければ，一連の実験を通して，他の力学パラメータとすべての形状パラメータとを一 定の值に保つ様に実験条件を制御しなければならない.

図 5 は，We と $S_{\mathrm{c}} / D$ との関係を示す。図 5 では三つの場合についての結果が，円形と菱形，三角形で表わさ れている. それぞれの場合において異なる寸法と流速，水温にて実験することにより，We と B 以外のす心゙て の支配パラメータが一定に保たれている. どの場合においても $S_{\mathrm{c}} / D$ の值がほぼ同じになることがわかる.この 結果は， $S_{\mathrm{c}} / D \sim \sigma W$ 効果は調査された $W e$ 範囲内で無視できること，または， $S_{\mathrm{c}} / D \sim \sigma B o$ 効果は調查された $B o$ 範囲内で無視できることを示す.よって，We> 12 において，式(6)は次式となる.

$S_{\mathrm{c}} / D=\Phi_{3}(F r, \operatorname{Re}, B / D, X / D, Z / D)$. 
または，Bo>95において，式(7)は次式となる.

$$
S_{\mathrm{c}} / D=\Phi_{4}\left(F r, R e / F r^{2}, B / D, X / D, Z / D\right) .
$$

厳密には，以下の二つの観点から，以上の二つの規範 $W e>12$ と $B o>95$ は過剩である. 第一に，すべての実 験が We > 12 かつ Bo > 95 で行われているため, Weや Bo がより小さい時の情報を欠いている. 第二に, 本実験 では，Frが $10^{0}$ のオーダーである，もし，Fr《1でさらに実験を行えば，より正確な We 規範を見出し得るだろ う。また， $F r » 1$ でさらに実験を行えば，より正確な $B o$ 規範を見出し得るだろう.

同様に厳密には，たとえ，より正確な規範を見い出したとしても，式(8)に対する $W e$ 規範の閾值が，理論的 に $F r や R e, B / D, X / D, Z / D$ のような他の支配パラメータに依存することや，式(9)に対する $B \mathrm{o}$ 規範の閾值が 理論的に $F r$ や $R e / F r^{2}, B / D, X / D, Z / D$ のような他の支配パラメータに依存することに注意しなければならない. 以上は，式(10)でも関連した話題について議論するが，具体的な閾值のパラメータ依存性については本論の対 象範囲外としており，今後の更なる研究が望まれる.

図 5 では, We 効果を無視できる様な We 範囲の下限界に関して, 他の研究者の規範も示している. これらの 規範は, “vertical orifice”や“horizontal orifice”のような簡単な流れ場に関するものであるが，それらはWe>12 と いう規範とさほど異ならない. Bo に関しては, 他の研究者の規範のいくつかが, 論文中に明記されていない為, 記述されていない. Anwar et al. (1978) では Bo > 1100 であり, Bo > 95 なる本評価基準とはかなり異なるが，Jain et al. (1978)による $B$ o > 55 なる規範は本規範に充分近い.

図 6一図 8 は, Re または $R e / F r^{2}$ に対する $S_{\mathrm{c}} / D$ を示す。図 6 および図 7, 図 8 は, それぞれ，值の異なる四つ の $B / D$ ，および，二つの $X / D ，$ 三つの $Z / D$ に関するものである. もちろん，各々の場合で，We と Bo を除き， $F r$ とす心゙ての形状パラメータを一定の值に固定している. よって, 各図では, We と Bo は, 一定に保たれてお らず, Re あるいは $R e / F r^{2}$ の值に応じて, それらの值を変える. しかしながら, 結果の大部分が $W e>12$ であり, 結果の大半が $B 0>95$ である. なお, 図中の破線が, これらの闇值を示す，従って，以下の議論では，We効果

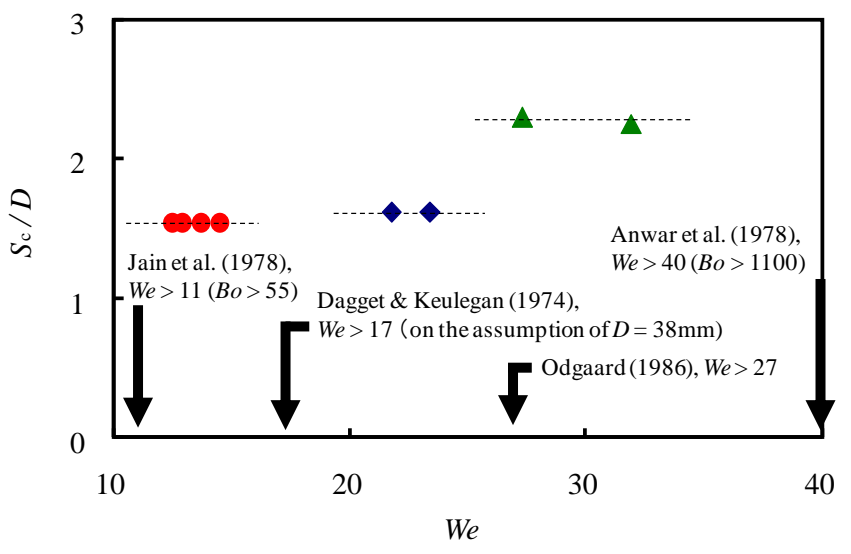

Fig. 5 Critical submergence $S_{d} D$ versus Weber number We: $, B / D=3.13, X / D=5.0, Z / D=0.48, F r=0.67$ and $R e=2.2 \times 10^{4}\left(\operatorname{Re}_{F r}{ }^{2}=4.9 \times 10^{4}, B o=380,420,440,470\right) ;$

$\checkmark, B / D=3.16, X / D=1.71, Z / D=0.71, F r=1.35$ and $R e=$ $3.8 \times 10^{4}\left(\operatorname{Re}_{F r}{ }^{2}=2.1 \times 10^{4}, B o=260,300\right) ; \boldsymbol{\Delta}, B / D=$ 3.16, $X / D=1.71, Z / D=0.71, F r=2.8$ and $R e=3.8 \times 10^{4}$ $\left(\operatorname{Re}_{F r}{ }^{2}=4.8 \times 10^{3}, B o=95,130\right)$.

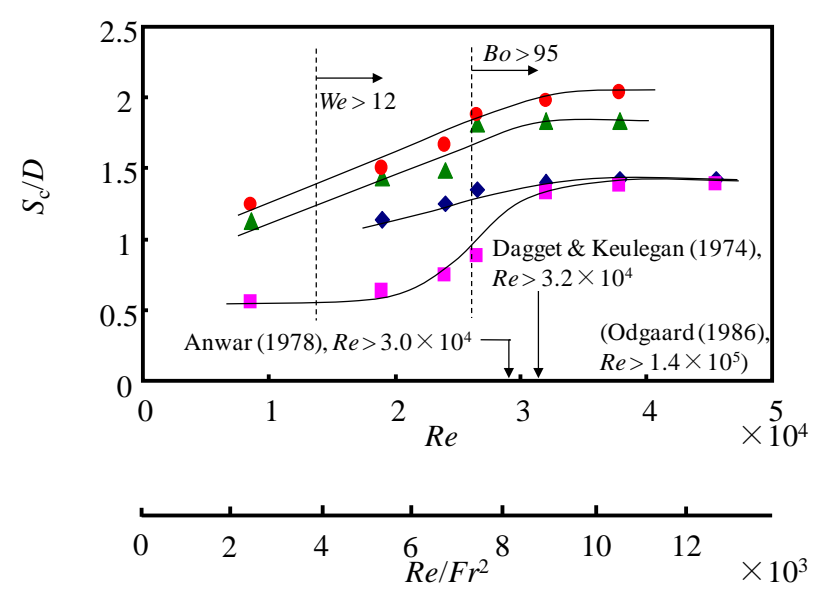

Fig. 6 Critical submergence $S_{\mathrm{d}} D$ versus Reynolds number $R e$, for several value of suction-sump breadth $B: \diamond, B / D=$ $1.43, X / D=2.11, Z / D=0.71, F r=1.9$ and $W e=15-27(B o$ $=62-198) ; \boldsymbol{\square}, B / D=2.11, X / D=2.11, Z / D=0.71, F r=1.9$ and $W e=8.7-27(B o=20-198) ; \boldsymbol{\Delta}, B / D=3.57, X / D=$ 2.11, $Z / D=0.71, F r=1.9$ and $W e=8.7-24(B o=20-155)$; , $B / D=4.21, X / D=2.11, Z / D=0.71, F r=1.9$ and $W e=$ 8.7-24 (Bo $=20-155)$. 
または Bo 効果を無視する．なぜならば，以下の議論では，We> 12 または $B o>95$ の結果だけを考察対象にし て，それぞれ， Re 効果または $\operatorname{Re}_{\mathrm{F}} \mathrm{r}^{2}$ 効果のみを専ら考える為である.

まず，図 6 を見る. Re が零から約 $3 \times 10^{4}$ まで増加する時, $S_{\mathrm{d}} / D$ は単調増加し, $R e>3 \times 10^{4}$ の範囲では, $S_{\mathrm{d}} / D$ は一定值を保つ. また, $R e / F r^{2}$ が零から約 $8 \times 10^{3}$ まで増加する時, $S_{\mathrm{c}} / D$ が単調増加し, $R e / F r^{2}>8 \times 10^{3}$ の範囲 では， $S_{\mathrm{c}} / D$ は一定值を保つ. よって， $S_{\mathrm{c}} / D へ の R e$ 効果は， $R e>3 \times 10^{4}$ の範囲で無視できることがわかる.ま たは， $S_{\mathrm{c}} / D へ の R e / F r^{2}$ 効果は, $R e / F r^{2}>8 \times 10^{3}$ の範囲で無視できることが分かる.

$R e$ に関する規範は, 実験範囲が $R e>1.4 \times 10^{5}$ に対する Odgaard (1986)による $R e>1.4 \times 10^{5}$ なる規範を除くと, Anwar et al.(1978)による Re > 3.0 × $10^{4}$ なる規範や Dagget \& Keulegan (1974) による Re $>3.2 \times 10^{4}$ なる規範と，よ く一致する. 図 7 と図 8 とは, 図 6 と異なる形状パラメータに注目した結果である. 図 7 と図 8 とでは, 図 6 と同様な傾向および同じ規範を確認できる. 従って, 式(8) と式(9)とは, $R e>3 \times 10^{4}$ あるいは $R e / F r^{2}>8 \times 10^{3}$ の条 件下で, 次式と見なせる.

$$
S_{\mathrm{c}} / D=\Phi_{5}(F r, B / D, X / D, Z / D) .
$$

厳密には, $W e$ と $B \mathrm{o}$ に関する規範と同様に, $R e>3 \times 10^{4}$ と $R e / F r^{2}>8 \times 10^{3}$ のような二つの規範は過剩である. なぜならば，図6一図 8 のすべての実験は $F r=1.9$ であり，100のオーダーである.もし，Fr《1で追加実験を 行えば，Reに関して，より正確な規範を見出し得るだろう。もし，Fr»1 で追加実験を行えば， $R e / F r^{2}$ に関し て，より正確な規範を見出し得るだろう。

同様に厳密には, たとえ式(10)における $R e$ や $R e / F r^{2}$ の規範の正確な閾值が分かったとしても, それらの閾值 は理論的に他の支配パラメータに依存することに注意すべきである. 事実, 図 8 では ZID の増加に従い, Re と $R e / F r^{2}$ との両闇值がわずかに増加することを確認できる.ただし, 図 6 と図 7 とにおける䦨值がそれぞれ $B / D$ と X/D との明確な影響を受けているとは, 認め難い. そして, 式(8)と式(9)とについての先の議論と同様,

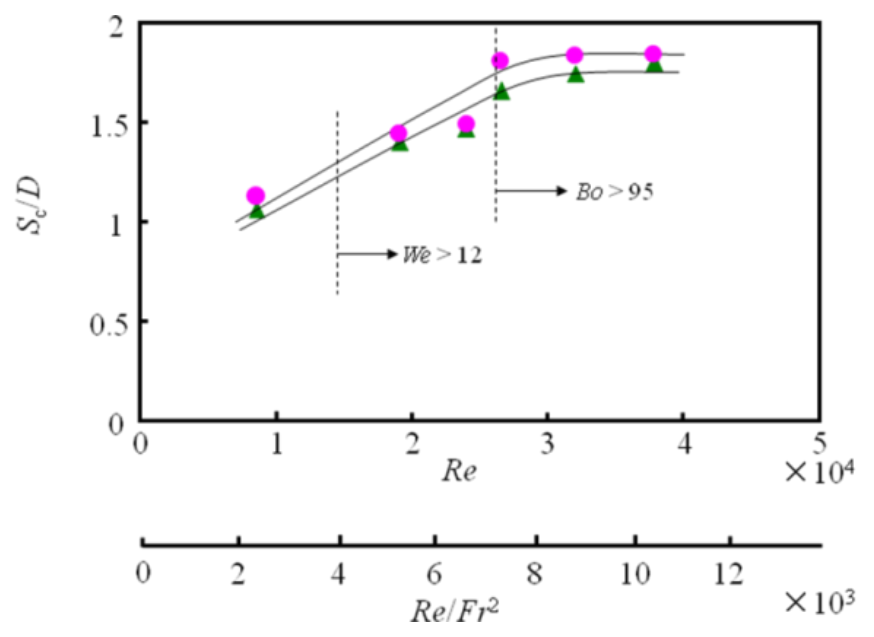

Fig. 7 Critical submergence $S_{\mathrm{C}} D$ versus Reynolds number $R e$, for several value of back clearance $X: \bigcirc / D=3.57$, $X / D=2.11, Z / D=0.71, F r=1.9$ and $W e=8.7-27(B o=$ 20-198); $\boldsymbol{\Delta}, B / D=3.57, X / D=2.52, Z / D=0.71, F r=1.9$ and $W e=8.7-27(B o=20-198)$.

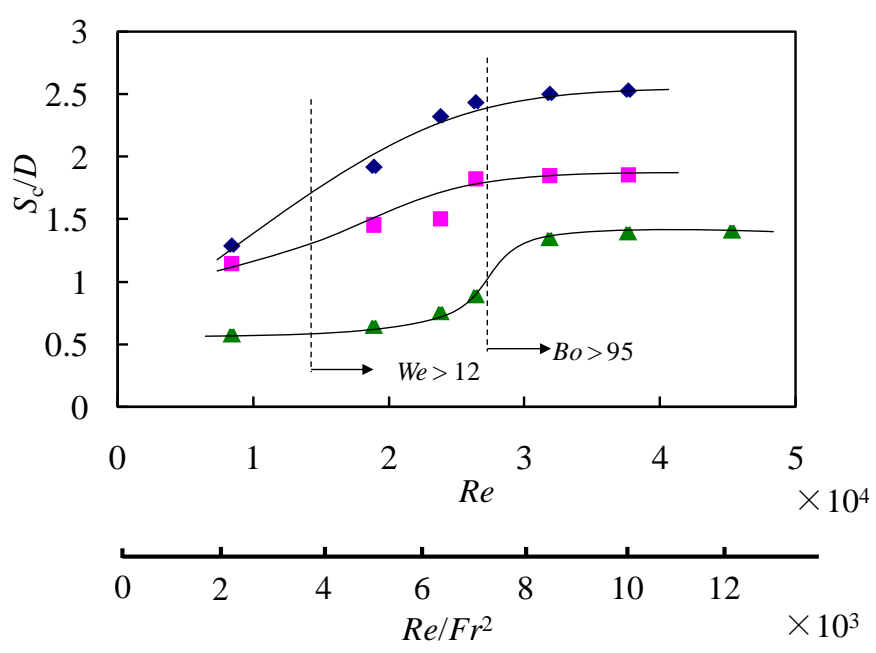

Fig. 8 Critical submergence $S_{\mathrm{c}} / D$ versus Reynolds number $R e$, for several value of bottom clearance $Z$ : $B / D=3.57, X / D=2.11, Z / D=0.26, F r=1.9$ and $W e=$ 8.7-21 (Bo=20-124); $\mathbf{\square}, B / D=3.57, X / D=2.11, Z / D$ $=0.71, F r=1.9$ and $W e=8.7-21(B o=20-124)$; $B / D=3.57, X / D=2.11, Z / D=1.43, F r=1.9$ and $W e=$ 8.7-24 (Bo $=20-155)$. 
$F r$ が両閾值に及ぼす影響は， $B / D$ や $X / D ， Z / D$ が両閾值に及ぼす影響と共に，本論の対象範囲外としており， 今後の更なる研究が望まれる。一般に, Fr の増加に伴い, Re の閾值は増加すると考えられる. なぜならば, $\operatorname{Fr}$ の増加は，一定の $R e$ での粘性力に対する重力の相対的減少を引き起こすからである. 対照的に，Frの増加 に伴い, $R e / F r^{2}$ の閾值は減少すると考えられる. なぜならば，Frの増加は，一定の $\operatorname{Re} / r^{2}$ での粘性力に対する 慣性力の相対的増大を引き起こすからである. よって, 以降に示す全ての結果は $\operatorname{Re}>3 \times 10^{4}$ ののである.つ まり, $R e$ 効果の議論を避ける為, $3 \times 10^{4}$ より充分大きな $R e$ を考える. 同様に, 以降に示寸全ての結果は $\operatorname{Re} / \mathrm{Fr}^{2}$ 効果の議論を避ける為, 図 9 を除き, $R e / F r^{2} » 8 \times 10^{3}$ のものである.

更に，図 6 および図 7 , 図 8 では，それぞれ，B/D および $X / D ， Z / D$ の $S_{\mathrm{c}} / D$ への効果を確認できる. 次の節 では，そのような形状効果を詳細に議論する。図 6一図 8 中の $R e>3 \times 10^{4}$ あるいは $\operatorname{Re} / F^{2}>8 \times 10^{3}$ で， $S_{\mathrm{c}} / D$ が取 り得る值の範囲を比較すると，B/D効果と $Z / D$ 効果は，X/D 効果より一見して強そうである. そして，三つの 効果とも，一見して複雑ではなさそうである。なぜならば， $B / D$ の増加につれても（図 6 を参照），あるいは， $X / D$ の減少につれても (図 7 を参照)，Z/Dの減少につれても (図 8 を参照)， $S_{\mathrm{c}} / D$ は単調増加する. しかしな がら，以上の結論は，B/D やX/D，Z/D などのパラメータの試験範囲に依存する（同様に $3 \cdot 3$ 節を参照）.

$R e<3 \times 10^{4}$ あるいは $\operatorname{Re} \mathrm{Fr}^{2}<8 \times 10^{3}$ での結果を考慮するときは, 粘性効果の為に, 他に別の注意が必要になる.

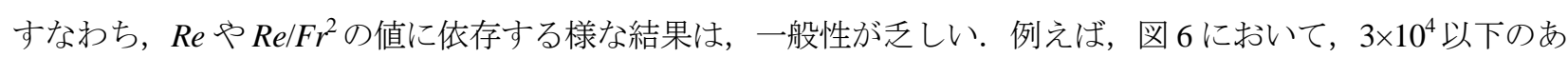
る一定值に保たれた $R e$ で, または, $8 \times 10^{3}$ 以下のある一定值に保たれた $R e / F r^{2}$ で, $S_{\mathrm{c}} / D$ は $B / D=2.11$ で極小值 を示す. 対照的に，（後に示されるが）粘性効果を無視できるくらい大きい Re/Fr ${ }^{2}$ るいはReにおいては，あ る $B / D$ の值で $S_{\mathrm{c}} / D$ は極大值を示す.

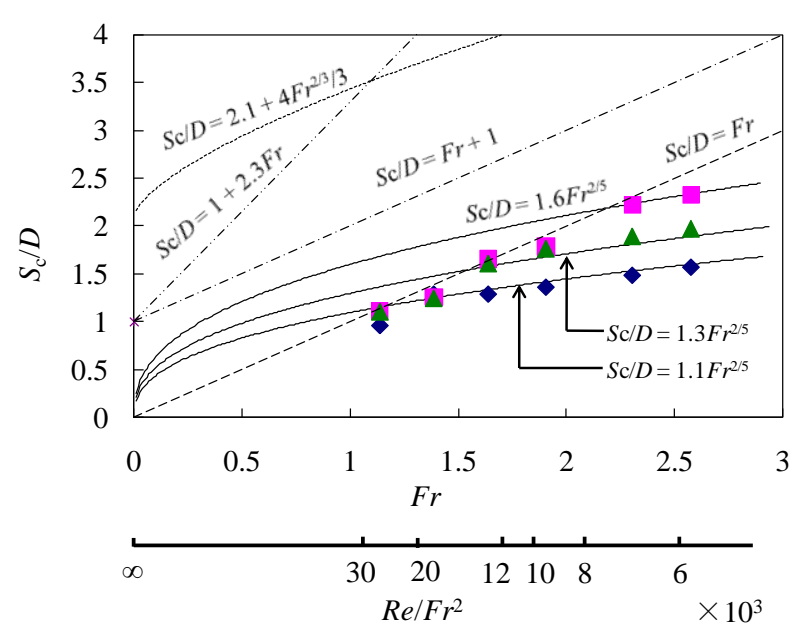

Fig. 9 Critical submergence $S / D$ versus Froude number $F r$, for several value of suction-sump breadth $B: \diamond, B / D=2.11$, $X / D=2.11, Z / D=0.71, R e=3.8 \times 10^{4}$ and $W e=20-26(B o=$ 105-309); $\mathbf{\square}, B / D=3.57, X / D=2.11, Z / D=0.71, R e=3.8$ $\times 10^{4}$ and $W e=20-26(B o=105-309) ; \boldsymbol{\Delta}, B / D=4.21, X / D$ $=2.11, Z / D=0.71, R e=3.8 \times 10^{4}$ and $W e=20-26(B o=$ 105-309). — and -. - - —, Reddy \& Pickford (1972); -..-..- , the 1998 HI Standard; ‥, Werth \& Frizell (2009).

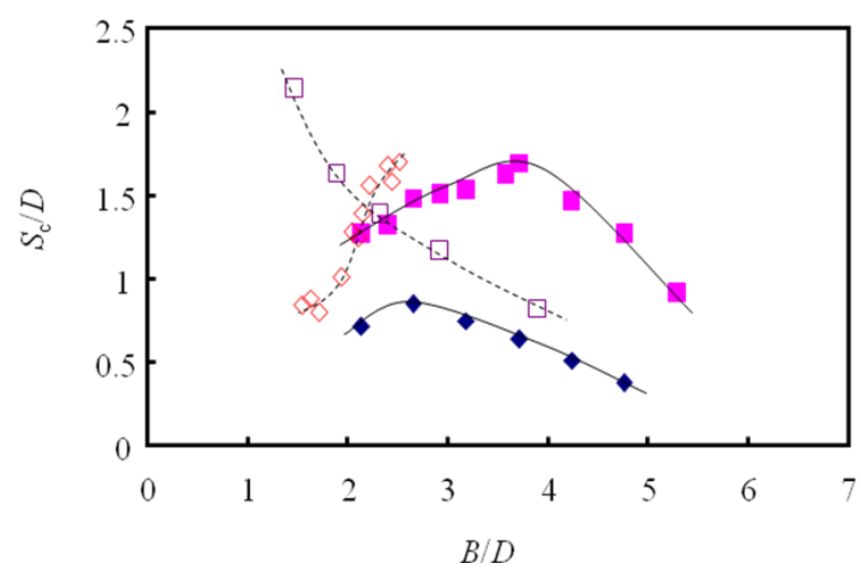

Fig. 10 Critical submergence $S_{\mathrm{d}} D$ versus suction-sump breadth $B$, for several value of back clearance $X$ : $=0.79, Z / D=0.71, F r=1.6, R e=3.8 \times 10^{4}$ and $W e=$ $22.4\left(\operatorname{Re}_{F r^{2}}=1.5 \times 10^{4}, B o=197\right) ; \boldsymbol{\square}, X / D=1.32, \mathrm{Z} / D$ $=0.71, F r=1.6, \operatorname{Re}=3.8 \times 10^{4}$ and $W e=22.4\left(R e / F r^{2}=\right.$ $1.5 \times 10^{4}$, Bo = 197); $\diamond$, Kitamura \& Kida (1971), X/D $=0.95, Z / D=0.48, F r=0.68-0.75$ and $R e=1.3 \times 10^{5}$; $\square$, Tagomori (1976), $X / D=0.92, Z / D=0.58, F r=0.68$ and $R e=1.0 \times 10^{5}$. 


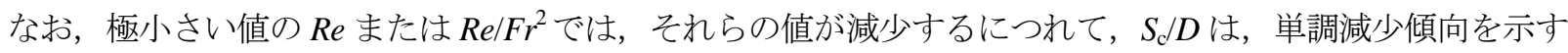
のではなく，むしろ，約 0.5 の一定值を保つ傾向も現れる (図 6 と図 8 とを参照)。この $S_{\mathrm{c}} D$ が一定值をとる 傾向は，タイプ(d)の空気吸込の発生に関係づけられることを確認した（Re が極小さくかつ $S_{\mathrm{c}} / D \lesssim 0.5$ では，タ イプ(d)が現れる.).

図 9 は，異なる $B / D$ の 三つケースにおける， $F r$ と $S_{\mathrm{c}} / D$ との関係を示す．もちろん，各ケース毎に，Re/Fr ${ }^{2}$ および We,$B o$ を除き，他の支配パラメータ $(R e$ や $B / D, X / D, Z / D)$ は一定值に保つ. 全ての結果は，We $>12$ かつ Bo > 95 であるので，We 効果や Bo 効果は共に無視できる. ただし，いくつかの結果は $\operatorname{Re}^{2} F r^{2}<8 \times 10^{3}$

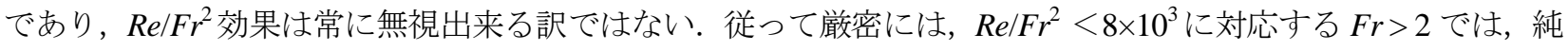
粋な $F r$ 効果が現れているとは限らず，粘性効果に影響を受けた Fr 効果 ( $F r$ 効果と $R e / F r^{2}$ 効果の複合効果)が 現れている可能性は否定できない.

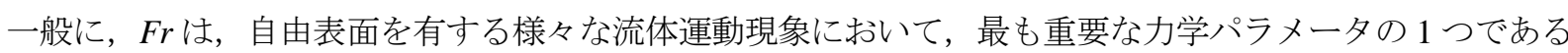

(Iversen (1953) と Farell \& Cuomo (1984)を参照)。図 9 からは，Fr が増加するにつれて， $S_{\mathrm{c}} / D$ は単調増加する ことがわかる．より詳しく述べると，Frが小さい時は， $S_{\mathrm{c}} / D$ は Fr に概ね比例する，一方，Frが大きい時は， $F r$ の増加に伴う $S_{\mathrm{d}} / D$ の増加率は, 一定值を保たず, むしろ減少傾向を示す. (この傾向は, $F r\left\langle 2\right.$ すおち $R e / F r^{2}>$ $8 \times 10^{3}$ でも認められることから，Re/Fr ${ }^{2}$ 効果とは無縁な $F r$ の純粋な効果と考えられる.）すなわち，Frが小さ い時は， $S_{\mathrm{c}} / D \propto F r$ なる関係により近似できそうである.（図中では，その比例定数は約 1 である.) 一方，Fr

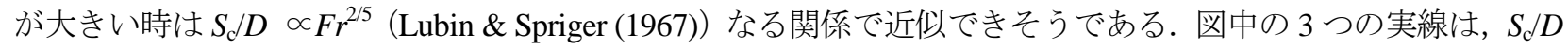
$\propto F r^{2 / 5}$ となる曲線群を示すが, 定性的には実験結果と同じ傾向と見做せそうである.（ただし，比例定数は形状 パラメータ $B / D$ と $X / D, Z / D$ の関数となるであろう.）Fr が小さい時と大きい時とは異なる傾向を示すことに ついて, 現時点では, その詳細は不明であり, 更なる研究が望まれる. ただし少なくとも, Frが小さい時に $S_{\mathrm{c}} / D$ が $F^{2 / 5}$ ではなくむしろ Fr に比例する事実は, Lubin \& Springer が導入した経験仮説（自由表面のくぼみから空 気糸への発達が急激であること）が Frが小さい時より大きい時の方が有効であろうから，合理的に思われる.

なお，図 9 には，他の研究者による，Fr と $S_{\mathrm{d}} D$ との関係式も示している. その内で, Reddy \& Pickford (1972) による $S_{\mathrm{c}} / D=F r$ なる経験式は，本実験とのよい対応を示す。他の三つの経験式，特に HI Standard (1998) と， Werth \& Frizell (2009) は，より大きな $S_{\mathrm{d}} / D$ を示す．なお，Werth \& Frizell の経験式にも，本研究と同様に，Fr の増加に伴う $S_{\mathrm{c}} / D$ 増加率の減少傾向が見られるが，彼らの減少傾向は，用いた Gulliver \& Rindels (1987) によ る実験結果のばらつきを反映している可能性が否定できない.

ところで, 図 9 では, $B / D$ が $S_{\mathrm{c}} / D$ 一及ぼす効果を確認することができる. 次の節では, そのような形状効果 について詳しく議論する。一見して，B/D効果は複雑ではなさそうである。実際, 図 9 では, $R e / F r^{2}>8 \times 10^{3}$ に 注目すると, $B / D$ の増加につれて $S_{\mathrm{c}} / D$ が単調増加する. しかしながら, この単調さは, 調査された $B / D$ の範囲 に依存することを後に示す. (3・3 節を参照).

\section{3 -3 形状パラメータの影響}

次に，三つの形状パラメータ $B / D$ および $X / D, Z / D$ の $S_{\mathrm{c}} / D$ への効果を考える.

図 10 は， $B / D$ と $S_{\mathrm{c}} / D$ との関係を示す。ここでは，異なる $X / D$ のつのケースを調べ，それらを図中の中実 菱形と中実正方形とで示す.もちろん, それぞれのケースで, $B / D$ 以外の全ての支配パラメータは一定に保つ. 両ケースで，四つの規範，すなわち，We $>12$ と $B o>95, R e>3 \times 10^{4}, R_{e} / F r^{2}>8 \times 10^{3}$ を全て満足していること に注意すべきである.よって, 本結果は, 一般性が保障されている. すなわち, We $>12$ かつ $B o>95, R e>3 \times 10^{4}$, $R e / F r^{2}>8 \times 10^{3}$ での, 得られる結果は全て同じになると考えられる. ちなみに, 図 10 中の中空菱形と中空正方 形は，それぞれ，北村と木田(1971)と田籠(1976)の実験結果を示す. 


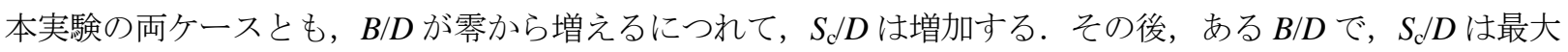
值に達する. さらに, $B / D$ が増すと, 逆に, $B / D$ の増加につれて $S_{\mathrm{d}} / D$ は減少する. この様に, $B / D$ 効果は複雑 である，例えば，田籠によると， $B / D$ の増加につれて， $S_{\mathrm{c}} / D$ は単調減少する. 一方, 北村と木田によると, 逆 に, $B / D$ の増加につれて $S_{\mathrm{d}} D$ は単調増加寸る. 今回の結果と彼らの結果との不一致は, 支配パラメータの不一 致に加え，彼らの $B / D$ 範囲が限られた狭さであることにより生じたと考えられる.

$B / D$ の増加に伴う $S_{\mathrm{c}} I D$ の増加傾向を, 直接説明することは難しそうである. この傾向は, 吸込管下流近傍で の渦形成への吸込水槽側壁の干渉が関係していることも考えられ（Funaki et al. (2008) を参照)，今後のより詳 細な研究が必要であろう。一方, $B / D$ の更なる増加に伴う $S_{\mathrm{d}} / D$ の減少傾向については, もし図 9 で見られる $S_{\mathrm{d}} / D$ に対する（全体的） Fr 効果を想定するならば，その理解は容易そうである. 寸なわち， $B / D$ の増加に伴い, 吸 込管入口近くの局所流速が減少することはありがちであろう. 局所流速の減少は対応する局所フルード数の減 少を引き起こす．もし適当な位置での局所フルード数が $S_{\mathrm{c}} / D$ に及ぼす効果もフルード数が $S_{\mathrm{d}} / D$ に及ぼす効果 と同傾向であると仮定するなら， $B / D$ 増加に伴う $S_{\mathrm{c}} / D$ の減少傾向は容認されよう. なぜなら, 空気吸込には, 全体的フルード数よりも吸込管入口近くの局所的フルード数のほうが，より決定的かつ効果的であると考えら れるからである。

図 11 は, $X / D$ と $S_{\mathrm{d}} / D$ との関係を示寸. ここでは, 異なる $B / D$ のつのケースを調べ，それらを図中の中実 菱形と中実正方形とで示寸.もちろん, それぞれのケースで, $X / D$ 以外の全ての支配パラメータは一定に保つ. より広い適用可能性を保障するため, 両ケースで, 四つの規範, 寸なわち $W e>12$ と $B o>95, R e>3 \times 10^{4}, R e / F r^{2}$ $>8 \times 10^{3}$ を全て満足している，ちなみに，図 11 中の中空菱形と中空正方形とは，それぞれ，五十畑ら(1975) と 田籠(1976)の実験結果を示す.

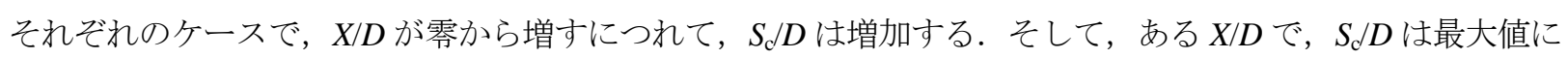
達する．X/Dがさらに増加するとき， $X / D$ の増加につれて $S_{\mathrm{d}} D$ は一定值に近づきながら減少する. この様な

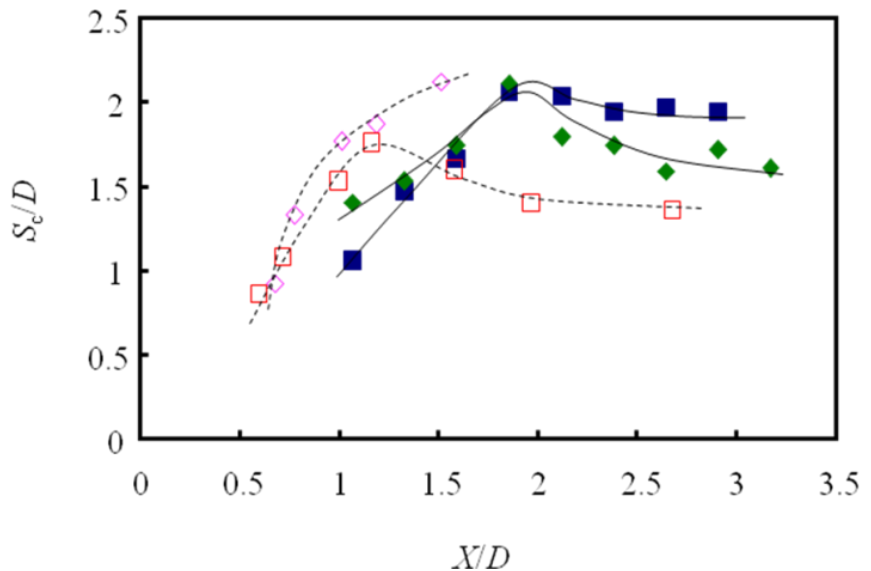

Fig. 11 Critical submergence $S / D$ versus back clearance $X$, for several value of sump breath $B: \diamond, B / D=3.16$, $Z / D=0.71, F r=1.6, R e=3.8 \times 10^{4}$ and $W e=22.4\left(R_{e} / F r^{2}=\right.$ $\left.1.5 \times 10^{4}, B o=197\right) ; \boldsymbol{\square}, B / D=4.21, Z / D=0.71, F r=1.6$, $R e=3.8 \times 10^{4}$ and $W e=22.4\left(\operatorname{Re}_{F} \mathrm{Fr}^{2}=1.5 \times 10^{4}, \mathrm{Bo}=197\right)$; $\diamond$, Isohata et al. (1975), $B / D=2.5, Z / D=0.60, F r=0.68$ and $R e=$ unknown; $\square$, Tagomori (1976), $B / D=2.3, Z / D=0.58$, $F r=0.68$ and $R e=1.0 \times 10^{5}$.

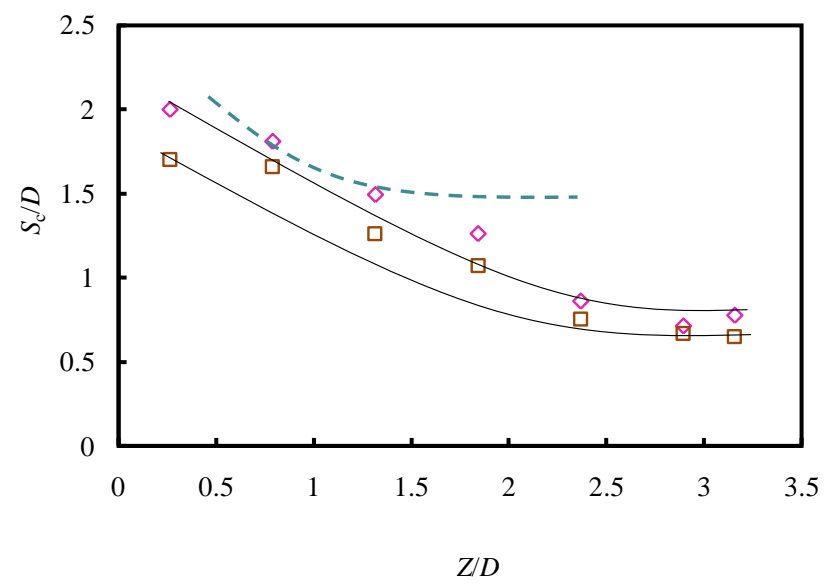

Fig. 12 Critical submergence $S_{\mathrm{d}} / D$ versus bottom clearance $Z: \diamond, B / D=3.16, X / D=2.11, F r=1.6, R e=3.8 \times 10^{4}$ and $W e$ $=22.4\left(\operatorname{Re}_{F} \mathrm{Fr}^{2}=1.5 \times 10^{4}, B o=197\right) ; \square, B / D=3.16, X / D=$ 2.52, $F r=1.6, R e=3.8 \times 10^{4}$ and $W e=22.4\left(R_{e} / F r^{2}=1.5 \times\right.$ $\left.10^{4}, B o=197\right) ; \quad---$, Kondo \& Maru (1972), $B / D=2.50$, $X / D=1.20, F r=1.3$ and $\operatorname{Re}=2.4 \times 10^{5}$. 
$X / D$ 効果は，田籠と定性的に同様であり，五十畑らよりも複雑である。つまり，五十畑らでは，X/Dの増加に つれて $S_{\mathrm{c}} / D$ が単調増加する. 今回の結果と彼らの結果との不一致は, 支配パラメータの不一致に加え, 彼らの $X / D$ 範囲が限られた狭さであることにより生じたと考えられる.

$B / D$ が零からある值まで増加するにつれて， $S_{\mathrm{c}} / D$ が増加する傾向（図 10 を参照）と同様に，上述の複雑な $X / D$ 効果を直接説明することは難しそうである. この複雑な効果を理解するためには, 吸込管下流近傍での渦 形成への吸込水槽背壁との干渉，あるいは，渦形成の背壁による増幅に関する更なる詳細な調査が必要であろ う。（Funaki et al. (2008)を参照).

図 12 は，ZID と $S_{\mathrm{c}} D$ との関係を示す。ここでは，異なる $X / D$ のつケースを調べ，それらを図中の中空菱 形と中空正方形とで示す。 もちろん，それぞれのケースで，ZID 以外の全ての支配パラメータは一定に保つ. より広い適用可能性を保障するため, 両ケースで, 四つの規範, すなわち $W e>12$ と $B o>95, R e>3 \times 10^{4}, R e / F r^{2}$ $>8 \times 10^{3}$ を全て満足している．ちなみに，図 12 中の破線は，近藤と丸(1972)の実験結果を示す.

$B / D$ がある值を超えてさらに増加するにつれて $S_{\mathrm{c}} / D$ が減少する傾向と同様 (図 10 を参照), Z/Dの増加につ れて $S_{\mathrm{c}} / D$ が減少する傾向を理解することは，もし図 9 で見られる $S_{\mathrm{c}} / D$ に対する（全体的） Fr 効果を想定する ならば，その理解は容易そうである。なぜならば，吸込管入口と吸込水槽底壁との間隙が広がるほど，局所流 速は低下しがちになるからである，局所流速の低下は，対応する局所フルード数の減少を引き起こす．よって 同様に，もし適当な位置での局所フルード数が $S_{\mathrm{c}} D$ に及ぼす効果も，フルード数が $S_{\mathrm{c}} / D$ にぼす効果と同傾 向であると仮定するなら，Z/D増加に伴う $S_{\mathrm{c}} / D$ の減少傾向は容認されよう.

更に述べると，Z/D>2.5 で， $S_{\mathrm{d}} / D$ は，小さな值を示す傾向がある．そして，その值は，Z/によらずほぼ一 定である.このことは，ある程度大きな $Z D$ では，吸込水槽底壁の存在の影響を無視できることを示唆してい る.

\section{4. 結言}

vertical wet-pit pump 形状を持つ吸込水槽／吸込管系での吸込管への空気吸込を考えた. 空気吸込発生につい ての最重要かつ慣例的指標である臨界没水深さ $S_{\mathrm{c}}$ に関して, 多くの実験を実施して, 主要な力学および形状パ ラメータが $S_{\mathrm{c}}$ 一及ぼす影響を明らかにした。結果は以下のとおりである.

(1) $S_{\mathrm{c}} \mathrm{D}$ への Fr, Re, We の三つの力学パラメータ効果を考えるとき, $R e$ 効果は $\operatorname{Re}>3 \times 10^{4}$ で無視でき, We 効果は $W e>12$ で無視できる.一方, $R_{e} / F^{2} r^{2}$ 効果は $R_{e} / F r^{2}>8 \times 10^{3}$ で無視でき, Bo 効果は $B o>95$ で無視できる. 前者は，Fr《1で，適当と考えられる．後者は，Fr»1で，適当と考えられる．実用的な観点からすると， Fr は多くの場合 1 よりもずっと大きくなることはないので，前者のみを考えればよいであろう。よって，通常， $R e>3 \times 10^{4}$ かつ We > 12 なる二つの規範の下で，ただ一つの力学パラメータ Fr のみを考えればよい. 純粋な $F r$ 効果としては, $F r$ が小さい時は $S_{\mathrm{c}} / D \propto F r, F r$ が大きい時は $S_{\mathrm{c}} / D \propto F r^{2 / 5}$ なる関係式が, 今回の実験結果に対 して概ねよい近似を与える。

(2)形状パラメータ $X / D, B / D, Z / D$ の $S_{\mathrm{c}} / D$ への効果を考えるとき，X/D効果と $B / D$ 効果に関しては，ある $X / D$ またはある $B / D$ で, $S_{\mathrm{c}} / D$ は最大值を示す。一方, Z/D効果は単調であるが, $Z / D>2.5$ のとき $S_{\mathrm{c}} / D$ は $Z / D$ に依存 しない一定の小さな值をとる.

これらの形状効果のいくつかの局面は， $S_{\mathrm{c}} / D$ に対する（全体的） Fr 効果を想定すると，容易に説明できる. 一方，他のいくつかの局面は，直接説明することが現段階では難しそうである. これらの局面を理解するため には, 吸込水槽内の複雑な流れ構造についての解明とその為の更なる詳細な調査が必要である. 流れ構造の正 確な把握は，空気発生に対して既往防止策の洗練や新たな防止策の発案にも有益となろう. 


\section{謝辞}

横浜国立大学，松本純博士ならびに熊本大学，宗像瑞恵博士より有益な助言を頂いた。本論文の編集には， 同志社大学，山口達郎氏と加治大伸氏の援助を受けた。ここに記して，感謝の意を表す.

\section{文献}

(1) Iversen, H. W., "Studies of Submergence Requirement of High Specific Speed Pumps,” Trans. of ASME, Vol. 75 (1953), pp. 635-641.

(2) Fraser, W. H. and Harrison, N. J., "Hydraulic Problems Encountered in Intake Structures of Vertical Wet-Pit Pumps and Methods Leading to Their Solution," Trans. of ASME, Vol. 75, No. 4 (1953), pp. 643-652.

(3) Denny, D. F., “An Experimental Study of Airentraining Vortices at Pump Sumps,” Proc. of IMechE, Vol. 170, No. 2 (1956), pp. 106-116.

(4) Stevens, J. C. and Kolf, R. C., "Vortex Flow through "Horizontal Orifices," Journal of the Sanitary Engineering Division, Proc. of ASCE, Vol. 83, No. SA6 (1957), pp. 1-22.

(5) Hattersley, R. T., "Hydraulic Design of Pump Intakes," Journals of the Hydraulics Division, Proc. of ASCE, Vol. 91, No. HY2 (1965), pp. 223-248.

(6) Granger, R., "Steady Three-Dimensional Vortex Flow," Journal of Fruid Mechanics, Vol. 25, No. 3 (1966), pp. $557-576$.

(7) Anwar, H. O., "Formation of a Weak Vortex," Journal of Hydraulics Research, Vol. 4, No. 1 (1966), pp. 1-16.

(8) Marris, A. W., “Theory of the Bathtub Vortex," Journal of Applied Mechanics, March (1967), pp. 11-15.

(9) Zielinski, P. B. and Villemonte, J. R., "Effect of Viscosity on Vortex-Orifice Flow," Journal of the Hydraulics Division, Proc. of ASCE, Vol. 94, No. HY3 (1968), pp. 745-752.

(10) Anwar, H. O., "Prevention of Vortices at Intakes," Water Power, October (1968), pp. 393-401.

(11) Domm, U., Rosemann, P. and Siekmann, H., "Modelluntersuchung der Einlaufstromung einer Groben Kuhlwasserpumpe," Zeitschrift für Flugwissenschaften, 19, Heft 8/9 (1971), pp. 374-379.

(12) 近藤正道，丸三郎，“ポンプ吸込管の長方形水槽における最小没水深さ”，日立評論，Vol. 54, No. 6 (1972), pp. 511-515.

(13) Reddy, Y. R. and Pickford, J.A., "Vortics at Intakes in Conventional Sumps,” Water Power, March (1972),pp. 108-109.

(14) Levi, E., "Experiments on Unstable Vortices," Journal of the Engineering Mechanics Division, Proc. of ASCE, Vol. 98, No. EM3 (1972), pp. 539-559.

(15) Dagget, L. L. and Keulegan, G. H., "Similitude in Free-Surface Vortex Formation," Journal of the Hydraulics Division, Proc. of ASCE, Vol. 100, No. HY11 (1974), pp. 1565-1581.

(16) Baum, M.R., "Gas Entrainment at the Free Surface of a Liquid: Entrainment Inception at a Laminar Vortex," Journal of British Nuclear Engineering System, Vol. 13 (1974), pp. 203-209.

(17) Baum, M. R. and Cook, M. E., "Gas Entrainment at the Free Surface of a Liquid: Entrainment Inception at a Vortex with an Unstable Gas Core,” Nuclear Engineering and Design, Vol. 32 (1975), pp. 239-245.

(18) Anwar, H. O., Weller, J. A. and Amphlett, M. B., "Similarity of Free-Vortex at Horizontal Intakes," Journal of Hydraulic Research, Vol. 16, No. 2, pp. 95-105 (1978).

(19) Jain, A. K., Ranga Raju, K. G. and Garde, R. J., "Vortex Formation at Pipe Intakes," Journal of the Hydraulic Division, Proc. of ASCE, Vol. 104, No. HY10 (1978), pp. 1429-1445.

(20) Hecker, G. E., "Model/Prototype Comparison of Free Surface Vortices," Journal of the Hydraulic Division, Proc. of ASCE, Vol. 107, No. HY10 (1981), pp. 1243-1259.

(21) Farell, C. and Cuomo, A. R., "Characteristics and Modeling of Intake Vortices," Journal of Engineering Mechanics, ASCE, Vol. 110, No. 5 (1984), pp. 723-742.

(22) Padmanabhan, M. and Hecker, G. E., "Scale Effect in Pump Sump Models," Journal of Hydraulic Engineering, ASCE, Vol. 110, No. 11 (1984), pp. 1540-1556. 
(23) Odgaard, A. J., "Free Surface Air Core Vortex," Journal of Hydraulic Engineering, ASCE, Vol.112, No.7 (1986), pp. 610-620.

(24) Gulliver, J. S. and Rindels, A. J., "Weak Vortices at Vertical Intakes," Journal of Hydraulic Engineering, ASCE, Vol. 113, No. 9 (1987), pp. 1101-1116.

(25) Takahashi, M., Inoue, A. and Aritomi, M., "Gas Entrainment at Free Surface of Liquid ( I )," Journal of Nuclear Science and Technology, Vol. 25, No. 2 (1988), pp. 131-142.

(26) Takahashi, M., Inoue, A. and Aritomi, M., “Gas Entrainment at Free Surface of Liquid (II),'Journal of Nuclear Science and Technology, Vol. 25, No. 3 (1988), pp. 245-253.

(27) Hite Jr., J. E. and Mih, W. C., "Verocity of Air-Core Vortics at Hydraulic Intakes," Journal of Hydraulic Engineering, ASCE, Vol. 120, No. 3 (1994), pp. 284-297.

(28) Yildirim, N. and Kocabas, F., "Critical Submergence for Intakes in Open Channel Flow," Journal of Hydraulic Engineering, ASCE, Vol. 121, No. 12 (1995), pp. 900-905.

(29) Yildirim, N. and Kocabas, F., "Critical Submergence for Intakes in Still-Water Reservoir," Journal of Hydraulic Engineering, ASCE, Vol. 124, No. 1 (1998), pp.103-104.

(30) Werth, D. and Frizzell, C., "Minimum Pump Submergence to Prevent Surface Vortex Formation," Journal of Hydraulic Research, Vol. 47, No. 1 (2009), pp. 142-144.

(31) 藤田憲次，大谷清，“ポンプの吸水槽について”，日立評論，別冊 Vol. 45 (1962), pp. 41-46.

(32) 京極武治，“立軸斜流ポンプの取水路（その 2) ”，ポンプ工学, Vol. 1, No. 3 (1965), pp. 160-165.

(33) 北村昇, 木田和夫, “ポンプ用吸込水そう計画上の問題点”, 日本機械学会誌, Vol. 74, No. 630 (1971), pp. 814-820.

(34) 五十畑悦郎，森垣誠太郎，宗実茂樹，沢田一由，“ポンプ取水槽設計上の問題点と対策”，三菱重工技報，Vol. 12, No. 1 (1975), pp. 33-40.

（35）田籠雅，“吸込水槽内のフローパターンと空気吸込渦（ベルマウス径と水槽諸寸法の影響）”，ターボ機械， Vol. 7, No. 8 (1976), pp. 451-460.

（36）窪田直和，“水槽形状と斜流ポンプの特性（特に低流量域における特性に関連して）”，電業社機械，Vol. 2, No. 2 (1978), pp. 30-35.

（37）新浜仁，角田隆晴，山本宜史，“自由表面をもつた吸込水槽の実験研究”，クボタ技報，No. 15 (1978), pp. 1-7.

(38) 岡本秀伸, 亀本喬司, 中口郁雄, “吸込水槽に発生する空気吸込渦・水中渦の間欠性”, 日本機械学会論文集 B編, Vol. 57, No. 536 (1991), pp. 1210-1213.

（39）田籠雅，上田治夫，“水中渦の発生とフローパターン”，日本機械学会論文集 B編，Vol. 57, No. 543 (1991), pp. 3641-3646.

(40) Arboleda, G. and El-Fadel, M., "Effects of Approach Flow Conditions on Pump Sump Design," Journal of Hydraulic Engineering, ASCE, Vol. 122, No. 9 (1996), pp. 489-494.

(41) Costantinescu, G. S. and Patel, V. C., "Numerical Model for Simulation of Pump-Intake Flow and Vortices," Journal of Hydraulic Engineering, ASCE, Vol. 124, No. 2 (1998), pp. 123-134.

(42) Funaki, J., Neya, M., Hattori, M., Tanigawa, H. and Hirata, K., "Flow Measurements in a Suction Sump by UVP," Journal of Fluid Science and Technology, JSME, Vol. 3, No. 1 (2008), pp. 68-79.

(43) Hirata, K., Saito, K., Hattori, M., Nakatani, Y. and Funaki, J., "Occurrence-Time-Ratio Measurements on Airentrainment in a Suction Sump,” Journal of Fluid Science and Technology, JSME, Vol. 4, No. 1 (2009), pp. 47-61.

(44) Prosser, M. J., The Hydraulic Design of Pump Sumps and Intakes,BHRA, Cranfield, Bedford, UK (1977).

（45）豊倉富太郎，“ポンプの吸込水槽の模型的試験法”，日本機械学会基準，JSME S 004，東京(1984).

(46) Claxton, J. et al., American National Standard for Pump Intake Design (the 1988HI Standard), ANSI/HI 9.8-1998, Hydraulic Institute, Parsippany, New Jersey, USA (1998).

(47) Lubin, B. T. and Springer, G. S., "The Formation of a Dip on the Surface of a Liquid Draining from a Tank," Journal of Fluid Mechanics, Vol. 29, Part 2, (1967), pp. 385-390.

(48) Jirka, G. H. and Katavola, D. S., "Supercritical Withdrawal from Two-Layered Fluid Systems Part 2: Three-Dimensional Flow into Round Intake,” Journal of Hydraulic Research, Vol. 17 (1979), pp. 53-62.

(49) Forbes, L. K. and Hocking, G. C., “The Bath-Plug Vortex,” Journal of Fluid Mechanics, Vol. 284 (1995), pp. $43-62$. 